DOI: http://doi.org/10.31617/k.knute.2019-03-19.69

\title{
ОПТИМІЗАЦІЙНІ ШЛЯХИ ВИБОРУ СТРУКТУРИ КОМПЛЕКСУ РЕКЛАМНИХ КОМУНІКАЦІЙ У ТУРИЗМІ
}

\author{
Транченко Л. В. \\ д.е.н., професор, завідувач кафедри \\ кафедра туризму та готельно-ресторанної справи \\ Уманський національний університет садівництва, Украӥна
}

Ключові слова: реклама, комунікація, туризм, Інтернет, послуга. Keywords: advertising, communication, tourism, Internet, service.

У недалекому минулому туристичні підприємства розглядали елементи рекламних комунікацій як окремі види діяльності. За умов сьогодення, інтеграція комплексу маркетингових рекламних комунікацій в туризмі необхідна для досягнення успіху підприємства. Поєднання різних елементів рекламного маркетингу для підтримки туристичного продукту є більш ефективним, ніж використання одного 3 них.

Туристичні підприємства зіштовхуються 3 однією серйозною проблемою при організації комплексу рекламних комунікацій [1, с. 7]. Вона полягає в тому, що пропоновані ними послуги не мають уречевленої форми, а отже, їх не бачить споживач. У зв'язку з цим, особливого значення набуває чіткий опис як самих послуг, так i вигод, які отримає клієнт від їх споживання.

Одним з етапів розробки рекламної комунікаційної стратегії $\epsilon$ оптимізація вибору структури комплексу маркетингових комунікацій. Вона являє собою поєднання окремих елементів просування (реклами, особистого продажу, пропаганди та стимулювання збуту) в комплексі комунікаційної стратегії підприємства [2, с. 293]. Рідко використовується тільки один елемент комунікацій. У більшості випадків підприємство прагне застосувати найбільш ефективне їх поєднання. Для цього в першу чергу необхідно визначити сильні і слабкі сторін кожного елемента.

Переваги реклами:

- привертає великий, географічно розкиданий ринок;

- доносить до споживача інформацію про підприємство;

- контролюється підприємством;

- добре поєднується з іншими елементами комунікацій і підвищує їх ефективність;

- може багаторазово повторюватися для однієї і тієї ж аудиторії;

- може видозмінюватися з часом; 
- забезпечує ефективну презентацію туристичного продукту;

- невеликі рекламні витрати в розрахунку на одного клієнта.

Недоліки реклами: не здатна на діалог $з$ потенційним клієнтом; стандартизованість рекламних звернень; не може обійтися без непотрібної аудиторії, тобто тих, для кого вона не призначена; вимагає великих загальних витрат .

Переваги особистого продажу: забезпечує особистий контакт 3 клієнтом і здатна на діалог з ним; викликає відповідну реакцію з боку потенційного споживача; може пристосовуватися до вимог окремих споживачів; концентрується на чітко визначених сегментах ринку; утримує постійних клієнтів.

Недоліки особистого продажу: високі витрати в розрахунку на одного потенційного споживача; не може охопити великий, географічно розкиданий ринок; вимагає значного розширення штату співробітників туристичного підприємства, що займаються реалізацією туристичного продукту/послуги.

Переваги стимулювання збуту: призводить до короткочасного зростання збуту і доповнює рекламу; містить явне спонукання до здійснення покупки; привертає увагу потенційних споживачів, пропонуючи їм яку-небудь поступку.

Недоліки стимулювання збуту: неможливість постійного застосування; може використовуватися тільки як додатковий елемент; є досить затратним.

Переваги пропаганди: надає потенційним покупцям достовірну інформацію про тур продукт/послугу; сприймається більш об'єктивно, ніж інформація, що виходить безпосередньо від турпідприємства; охоплює широке коло потенційних споживачів; створює можливості для ефектного представлення турпродуктів.

Недоліки пропаганди: висока вартість окремих заходів; нерегулярність, разовість публікацій; преса може акцентувати увагу потенційних споживачів на другорядних, несуттєвих характеристиках туристичних продуктів; відсутність гарантій формування позитивного іміджу туристичного підприємства i пропонованих ним на ринку туристичних продуктів/послуг.

Таким чином, кожен елемент рекламної комунікації повинен застосовуватися чітко за призначенням з урахуванням тих обмежень, які він сам на себе накладає. При цьому необхідно визначити умови ефективності того чи іншого елемента. Загальна умова ефективності всіх елементів комплексу комунікацій виглядає досить просто: витрати на конкретний елемент просування повинні бути менше (або принаймні рівні) приросту доходів, отриманих в результаті їх 
використання. Так, бюджетне обмеження для невеликих туристичних фірм дає змогу відхилити багато видів дороговартісної реклами. Інші умови ефективності маркетингових комунікацій залежать від таких факторів, як особливості продукту/послуги, що просувається і стадія життєвого циклу, рівень конкуренції на ринку, ступінь готовності потенційних споживачів звернутися до послуг туристичного підприємства, а також конкретних умов, що склалися у певний момент на ринку.

Отже, кожному елементу комплексу рекламних комунікацій притаманні специфічні прийоми і методи. Проте всі вони переслідують одну мету - сприяти успішному вирішенню стратегічних і тактичних завдань реалізації концепції маркетингу. Завдяки правильному поєднанню i використання всіх складових елементів комплексу маркетингу забезпечується так зване просування на ринок. Виходячи з обраної стратегії рекламних комунікацій, здійснюється підготовка i проведення конкретних маркетингових заходів.

\title{
Список використаних джерел
}

1. Кожухівська Р. Б. Інвестиційна привабливість рекламного ринку України на основі Інтернет-комунікацій / Р. Б. Кожухівська // Інвестиції: практика та досвід. - 2012. - № 5. - С. 7-11. - Режим доступу: nbuv.gov.ua/UJRN/ipd_2012_5_4.

2. Транченко Л. В. Вплив інформаційних технологій на маркетинг у сфері туризму / Л. В. Транченко // Економіка і організація управління, 2014. - № 1(17). - С.292-296.

DOI: http://doi.org/10.31617/k.knute.2019-03-19.71

\section{СУЧАСНІ ТЕНДЕНЦІї ФОРМУВАННЯ РЕКЛАМНОГО БІЗНЕСУ В УКРАЇНI}

\author{
Хамініч С. Ю. \\ д.е.н., професор \\ Рохліна М. C. \\ магістр \\ кафедра економічної теорії та маркетингу \\ Дніпровський начіональний університет ім.О.Гончара, Украӥна
}

Ключові слова: рекламна кампанія, реклама.

Keywords: advertising campaign, advertising. 